\title{
FACTORS THAT INFLUENCE ON REPRODUCTIVE EFFICIENCY IN KARADI AND AWASSI SHEEP RAISED UNDER TRADITIONAL CONDITIONS
}

\author{
HAWAR M. H. ZEBARI \\ Dept. of Animal Production, College of Agricultural Engineering Sciences, University of Duhok, \\ Duhok, Kurdistan region-Ira
}

(Received: August 26, 2020; Accepted for Publication: September 19, 2020)

\begin{abstract}
Poor reproductive efficiency is considered one of the main causes of declining sheep production in sheep raised under traditional farm conditions. Many factors contribute to declining reproductive performance in ewes. The objective of the present study was to investigate factors that affect reproductive efficiency in Karadi and Awassi sheep raised under farm conditions. Four hundred Karadi and Awassi sheep (200 Karadi and 200 Awassi) were used in this study. Of each breed 100 ewes were allowed to come into oestrus spontaneously and another 100 ewes were synchronized using intravaginal sponges. Ewes were injected with intramuscular injection of 500 IU of PMSG when sponges were removed at 14 days.

This study revealed that the breed had a significant effect on twinning rate and lamb mortality rate in spontaneous ewes. Breed also had a significant effect on the rate of lambing, lamb mortality, abortion, and dystocia in synchronized ewes. In addition, parity had a significant effect on the rate of lambing, lamb mortality and dystocia in spontaneous Karadi and Awassi ewes. Furthermore, parity also had significant effect on the rate of lambing, lamb mortality, dystocia and barrenness in synchronized Karadi and Awassi ewes. Different ram to ewe ratio during the oestrus period had a significant effect on conception rate and barrenness rate in synchronized Karadi and Awassi ewes. In conclusion, breed had effect on some reproductive parameters in synchronized and spontaneous ewes. Parity 2 had higher reproductive performance than parity 1 and parity $\geq 3$ ewes. Conception rate were higher in 1:8 ram to ewe ratio group, while $1: \geq 16$ ram to ewe ratio group had higher barrenness rate.
\end{abstract}

KEYWORDS: Karadi ewes; Awassi ewes; synchronized; fertility; conception; parity

\section{INTRODUCTION}

$\mathbf{R}$ recently, there has been an increasing interest in the understanding of the influence of some factors on productivity efficiency in sheep. Therefore, to maintain high reproductive performance in Karadi and Awassi sheep flocks under traditional conditions, identifying factors that influence reproductive efficiency are critically important (Juma and Alkass, 2005; Zebari et al., 2018). Karadi and Awassi are the local breed of sheep in Kurdistan region and Iraq (Alkass and Abdulkareem, 2004), and are considered the most important sheep breed in the semi-arid regions of the middle east countries (Galal et al., 2008). The breeding season of local ewes starts as early as April and lasts through September. The reproductive performance of Kardi and Awassi sheep has been low ((Juma and Alkass, 2005).
The factors that influence on reproductive efficiency of Karadi and Awassi are unclear. In reproductive planning of sheep, breed, parity and ram to ewe ratio of the ewe are factors which have a great effect on fertility results (Buckley et al., 2003). Conception rate, litter size or percentage of lambs born to ewe (Abdulkareem and Eidan, 2014), number of ewe lambed, abortion, parturition dystocia and mortality rate after birth are considered the main aspects in sheep reproductive performance (Evans, 2003).

In general, productivity and profitability can be determined by reproductive performance of sheep. Fertility in sheep is influenced by breed (Gaskins et al., 2005), hormonal status (Taha and Alkass, 2011), parity and age (Abegaz et al., 2002) ram to ewe ratio during breeding season (Crosby et al., 1991). There is limited studies reported the effect of rams to ewes ratio and 
introduced ram after progestogen sponge withdrawal in an attempt to increase the reproductive efficiency in sheep (Lucidi et al., 2001). However, there is also a paucity of published information on the factors that influence reproductive performance in Karadi and Awassi sheep raised under traditional conditions. Therefore, the present study was designed to investigate whether the reproductive performance of Karadi and Awassi sheep are affected by breed, parity, and ewe to ram ratio.

2. Materials and methods: The experiment was undertaken between June 2019 and May 2020 at three traditional sheep farms in Akre, Duhok Governorate. The Ethics Committee from Department of Animal Production, in College of Agricultural Engineering Sciences, University of Duhok approved the research protocol.

2.1. Experimental animal, housing and management: Four hundred Karadi and Awassi sheep (200 Karadi and 200 Awassi) were used at three traditional sheep farms in Akre, Duhok Governorate. At the start of the study, the Ewe and Rams were submitted for detection of any abnormalities of the reproductive tract. The sheep were housed in a free stall yard during night and sheep were put out to graze during the day in the spring and summer seasons and continuously housed during winter. During housing total mixed ration (TMR; hay, barley and wheat barn) was provided daily, sufficient for ad libitum availability. Water was also provided ad libitum from water troughs at the free stall yard and at pasture during the spring and summer.

2.2. Oestrus synchronization: Each Karadi and Awassi ewes were randomly divided into two groups. The first group $(\mathrm{n}=100$ Karadi and $\mathrm{n}=100$ Awassi ewes) were allowed for coming into oestrus spontaneously. Second group ( $n=100$ Karadi and $n=100$ Awassi ewes) were synchronized using intravaginal sponges composed of polyurethane sponge soaked with $60 \mathrm{mg}$ of medroxyprogesterone acetate/sponge (ESPONJAVET, HIPRA, Girona, SPAIN). The injections of pregnant mare serum gonadotropin (PMSG; $500 \mathrm{IU}$ ) were carried out in 14 days after the withdrawal of the vaginal sponges. The active fertile rams were introduced to ewe $48 \mathrm{hrs}$ after the removal of sponges according to ram to ewe ratio $(1: 10,1: 15$ and $1: \geq 16)$.

\subsection{Data collection}

2.3.1. Reproductive parameters: Fertility rate, conception rate, litter size (prolificacy), lambing (\%), twinning rate, abortion rate, dystocia rate, lamb mortality rate after birth to weaning, barrenness and productivity were calculated according to Taha and Alkass (2011) as below:

1. Fertility rate $=($ No. of ewes lambed $/$ no. of ewes exposed to ram) $\mathrm{x} 100$

2. Conception rate $=$ (No. of ewes lambed+aborted/no. of ewes exposed to ram)x 100

3. Litter size (Prolificacy) $=$ No. of lamb born / no. of ewes lambed

4. Lambing rate $=($ No. of lamb born $/$ no. of ewes exposed to ram) $\mathrm{x} 100$

5. Twining rate $=$ (No. of lamb born twins $/$ no. of ewes exposed to ram) x 100

6. Abortion rate $=$ (No. of ewes aborted / no. of ewes exposed to ram) $\mathrm{x} 100$

7. Dystocia rate $=$ (No. of ewes lambed with dystocia / no. of ewes lambed) x 100

8. Lamb mortality rate $=($ No. of lamb died $/$ no. lamb weaned) $\mathrm{x} 100$

9. Barrenness rate $=$ (No. of ewes failed to lamb / no. of ewes exposed to ram) $\mathrm{x} 100$

10. Productivity $=$ Fertility $X$ Prolificacy $X$ survival rate or (No of lambed weaned / no. of ewes exposed to ram) $\mathrm{x} 100$

2.3.2. Effect of breed: Karadi ewes $(n=200)$ and Awassi ewes $(n=200)$ were randomly chosen from three flocks of sheep. These were used to analyses for the effect of breed on the reproductive efficiency in Karadi and Awassi ewes.

2.3.3. Parity of ewes: Reproductive parameters were analysed according to the parity of both spontaneous and synchronized ewes. There was no differences $(\mathrm{P}=0.651$; Karadi and $\mathrm{P}=0.521$; Awassi ewes) between ewes that were in parity 3 , 4 and 5. Therefore parity 3, 4 and parity 5 were considered as one group ( $\geq 3^{\text {rd }}$ parity ewes). Corresponding to ewes in their $1^{\text {st }}, 2^{\text {nd }}$ and $\geq 3^{\text {rd }}$ parity, ewes were grouped into $1^{\text {st }}, 2^{\text {nd }}$ and $\geq 3^{\text {rd }}$ parity and in accordance with the parity data, the effect of parity on the ewes reproductive efficiency were analysed.

2.3.4. Ram to the ewe ratio: Active fertile rams were introduced to synchronized ewe after the removal of sponges with three different ratio $1: 8$, $1: 12$ and $1: \geq 16$. However, ewes coming into oestrus spontaneously around breed season, were mated randomly without control of ram groups. Therefore, the data of spontaneous oestrus ewes were ignored. In accordance to the ram to ewe ratio, data of synchronized ewes were analysed to identify the effect of ram to ewe ratio on the reproductive efficiency. 
2.4. Statistical analysis: Statistical analyses were performed using the Genstat statistical software package (Genstat 18th edition, 18.1.14713, VSN International Ltd, UK). All of the data sets analysed were normally distributed. Chi-Square tests were used to compare the reproductive parameters $(0 / 1)$ of the fertility rate, conception rate, abortion rate, dystocia rate, lamb mortality rate from birth to weaning, barrenness and productivity between Karadi and Awassi breed, parity 1,2 and $\geq 3$ and ram to ewe ratio $1: 8,1: 12$ and $1: \geq 16$. Chi-Square tests were also used to compare reproductive performance (1/2) of litter size, lambing rate and twinning rate between Karadi and Awassi breed, parity 1, 2 and $\geq 3$ and ram to ewe ratio 1:8, 1:12 and $1: \geq 16$. Tukey test were used to compare between different groups of parity and ram to ewe ratio. Differences were reported as significant at $\mathrm{P}<0.05$ and trends were reported when $P$ is between $<0.1$ and $>0.05$.

\section{RESULTS}

3.1. Effect of breed (Karadi vs Awassi ewes) 3.1.1. Spontaneous Karadi vs spontaneous Awassi ewes

A summary of the effect of breed which had spontaneous oestrus are presented in Table 1. The results show that the twinning rate $(P=0.027)$ and lamb mortality rate after birth to weaning $(P=0.054)$ were affected by breed. A higher twinning rate $(12.50 \%$ vs $7.69 \%)$ and mortality rate after birth to weaning $(2.22 \%$ vs $0.00 \%)$ in Awassi ewes compared to Karadi ewes, respectively. However, there were no differences in the rate of fertility $(P=0.425)$, conception $(P=0.368)$, litter size of prolificacy $(P=0.207)$, lambing $(P=0.107)$, abortion $(P=0.155)$, dystocia $(P=0.361), \quad$ barrenness $\quad(P=0.426) \quad$ and productivity $(P=0.215)$ between two breeds.

Table (1): Effect of breed on reproductive performance in spontaneous Karadi $(n=100)$ and Awassi $(\mathrm{n}=100)$ ewes.

\begin{tabular}{|c|c|c|c|}
\hline & Spontaneous estrus s & & \\
\hline \multirow[t]{2}{*}{ Reproductive traits } & Karadi Sheep $(n=100)$ & Awassi sheep $(n=100)$ & \multirow[t]{2}{*}{$P$ value } \\
\hline & Number (\%) & Number (\%) & \\
\hline Fertility rate & 78.00 & 80.00 & 0.425 \\
\hline Conception rate & 82.00 & 85.00 & 0.368 \\
\hline Litter size or prolificacy & 1.07 & 1.12 & 0.207 \\
\hline Lambing rate & 84.00 & 90.00 & 0.107 \\
\hline Twinning rate & 7.69 & 12.50 & 0.027 \\
\hline Abortion rate & 4.00 & 5.00 & 0.155 \\
\hline Dystocia rate & 1.28 & 1.25 & 0.361 \\
\hline Mortality rate after birth & 0.00 & 2.22 & 0.054 \\
\hline Barrenness rate & 18.00 & 15.00 & 0.426 \\
\hline Productivity rate & 84.00 & 88.00 & 0.215 \\
\hline
\end{tabular}

\subsubsection{Synchronized Karadi vs synchronized} Awassi ewes

Regarding the effect of synchronized Karadi $v s$ synchronized Awassi ewes, abortion rate $(P<0.01)$ and dystocia rate $(P<0.001)$ were higher in Karadi ewes compared to Awassi ewes $(5.00 \%$ vs $3.00 \%$ and $4.70 \%$ vs $2.22 \%$, respectively). However, higher lambing rate
$(P=0.051)$ and lamb mortality rate from birth to weaning $(P=0.04)$ were recorded in Awassi compared to Karadi ewes (114\% vs $107 \%$ and $0.92 \%$ vs $3.45 \%$, respectively). There were no differences in the fertility rate $(P=0.192)$, conception rate $(P=0.195)$, prolificacy $(P=0.281)$, twinning $(P=0.217)$, barrenness $(P=0.192)$ and productivity $(P=0.454)$ rate (Table 2). 
Table (2): Effect of breed on reproductive performance in synchronized Karadi ( $n=100)$, Awassi $(\mathrm{n}=100)$ ewes.

\begin{tabular}{|c|c|c|c|}
\hline \multirow{3}{*}{ Reproductive traits } & \multicolumn{2}{|c|}{ Synchronized estrus sheep $(n=200)$} & \multirow{3}{*}{$P$ value } \\
\hline & Karadi Sheep $(n=100)$ & Awassi sheep $(n=100)$ & \\
\hline & Number (\%) & Number (\%) & \\
\hline Fertility rate & 85.00 & 91.00 & 0.192 \\
\hline Conception rate & 90.00 & 94.00 & 0.195 \\
\hline Litter size or prolificacy & 1.26 & 1.27 & 0.281 \\
\hline Lambing rate & 107.00 & 114.00 & 0.051 \\
\hline Twinning rate & 25.90 & 27.50 & 0.217 \\
\hline Abortion rate & 5.00 & 3.00 & $<0.01$ \\
\hline Dystocia rate & 4.70 & 2.22 & $<0.001$ \\
\hline Mortality rate after birth & 0.93 & 3.45 & 0.04 \\
\hline Barrenness rate & 10.00 & 6.00 & 0.192 \\
\hline Productivity rate & 106.00 & 112.00 & 0.454 \\
\hline
\end{tabular}

\subsection{Effect of parity of ewes}

\subsubsection{Effect of parity on spontaneous Karadi and Awassi ewes}

Regarding the effect of ewe parity $(1,2$ and $\geq 3$ ewes) on reproductive parameters in Karadi ewes which had spontaneous oestrus (Table 3), lambing rate $(75.00 \%)$ was lower $(P=0.018)$ in parity 1 ewes compared to parity 2 ewes $(84.85 \%)$ and $\geq 3$ ewes $(86.70 \%)$, while there were no significant different between parity 2 and $\geq 3$ ewes. However, dystocia rate $(P=0.033)$ was higher in parity 1 ewes $(5.00 \%)$ compared to parity $2(0.00 \%)$ and $\geq 3$ ewes $(0.00 \%)$, but there was no significant different between parity 2 and $\geq 3$ ewes. Lamb mortality rate was higher $(P=0.027)$ in parity 1 ewes $(6.70 \%)$ in comparison to parity 2 ewes $(0.00 \%)$ and $\geq 3$ ewes $(0.00 \%)$. While there were no different in fertility rate $(\mathrm{P}=140)$, conception rate $(P=0.262)$, litter size or prolificacy $(P=445)$, barrenness rate
$(P=0.116)$ and abortion rate $(P=168)$ between parity 1,2 and $\geq 3$ Karadi ewes.

The effect of parity 1,2 and $\geq 3$ on spontaneous Awassi ewes' reproductive efficiency are presented in Table 4. Lambing rate was higher $(97.29 \% ; P=0.054)$ in parity 2 Awassi ewes compared to parity 1 and $\geq 3$ ewes. While the lamb mortality rate $(0.00 \% ; P=0.051)$ and the barrenness rate $(11.43 \% ; P=0.045)$ were lower in parity 2 Awassi ewes compared to parity 1 and $\geq 3$ ewes and there was no significant difference between parity 1 and $\geq 3$ ewes. Dystocia rate was higher $(P=0.020)$ in parity 1 ewes $(4.00 \%)$ compared to parity 2 ewes $(0.00 \%)$ and $\geq 3$ ewes $(0.00 \%)$, while there were no significant differences between parity 2 and $\geq 3$ ewes. There were also no differences in fertility rate $(P=0.110)$, conception rate $(P=0.130)$, litter size or prolificacy $(P=0.321)$ and abortion rate $(P=265)$ between parity 1,2 and $\geq 3 \quad$ Awassi ewes. 
Table (3): Effect of parity on reproductive performance in spontaneous Karadi ( $n=100)$ ewes.

Spontaneous estrus Karadi Sheep $(n=100)$

\begin{tabular}{|c|c|c|c|c|}
\hline \multirow[t]{2}{*}{ Reproductive traits } & \multicolumn{3}{|c|}{ Parity of sheep } & \multirow[t]{2}{*}{$P$ value } \\
\hline & Parity 1, n=20 (\%) & Parity 2, n=35 (\%) & Parity $\geq 3, n=45(\%)$ & \\
\hline Fertility rate & 75.00 & 80.00 & 77.00 & 0.140 \\
\hline Conception rate & 80.00 & 82.90 & 82.20 & 0.262 \\
\hline Litter size or prolificacy & 1.00 & 1.04 & 1.06 & 0.445 \\
\hline Lambing rate & $75.00^{b}$ & $84.85^{\mathrm{a}}$ & $86.7^{\mathrm{a}}$ & 0.018 \\
\hline Abortion rate & 5.00 & 2.86 & 4.44 & 0.168 \\
\hline Dystocia rate & $5.00^{\mathrm{a}}$ & $0.00^{\mathrm{b}}$ & $0.00^{\mathrm{b}}$ & 0.033 \\
\hline Mortality rate after birth & $6.70^{\mathrm{a}}$ & $0.00^{b}$ & $0.00^{\mathrm{b}}$ & 0.027 \\
\hline Barrenness rate & 20.00 & 17.20 & 17.80 & 0.116 \\
\hline \multicolumn{5}{|c|}{$\begin{array}{l}\text { Rates within rows with different superscript letters are significantly different }(\mathrm{P} \leq 0.05) \text {. } \\
\text { Table (4): Effect of parity on reproductive performance in spontaneous Awassi }(\mathrm{n}=100) \text { ewes. }\end{array}$} \\
\hline \multicolumn{5}{|c|}{ Spontaneous estrus Awassi Sheep $(n=100)$} \\
\hline \multirow[t]{2}{*}{ Reproductive traits } & \multicolumn{3}{|c|}{ Parity of sheep } & $P$ value \\
\hline & Parity 1, n=25 (\%) & Parity 2, n=37 (\%) & Parity $\geq 3, n=38(\%)$ & \\
\hline Fertility rate & 76.00 & 86.49 & 76.32 & 0.110 \\
\hline Conception rate & 80.00 & 91.89 & 81.59 & 0.130 \\
\hline Litter size or prolificacy & 1.11 & 1.25 & 1.14 & 0.321 \\
\hline Lambing rate & $84.00^{b}$ & $97.29^{a}$ & $86.84^{b}$ & 0.054 \\
\hline Abortion rate & 4.00 & 5.40 & 5.26 & 0.265 \\
\hline Dystocia rate & $4.00^{a}$ & $0.00^{b}$ & $0.00^{b}$ & 0.020 \\
\hline Mortality rate after birth & $4.80^{\mathrm{a}}$ & $0.00^{\mathrm{b}}$ & $3.03^{\mathrm{a}}$ & 0.051 \\
\hline Barrenness rate & $16.00^{\mathrm{a}}$ & $11.43^{b}$ & $18.42^{\mathrm{a}}$ & 0.045 \\
\hline
\end{tabular}

Rates within rows with different superscript letters are significantly different $(\mathrm{P} \leq 0.05)$.

\subsubsection{Effect of parity on synchronized Karadi and Awassi ewes}

A summary of the effect of parity 1,2 and $\geq 3$ on the reproductive efficiency in synchronized Karadi ewes are presented in Table 5. The results show that the percentage of lambing was higher $(P=0.018)$ in parity 2 (116.60\%) compared to parity 1 ewes (104.50\%) and parity $\geq 3$ Karadi ewes $(102.10 \%)$. The rate of barrenness was lower $(P=0.014)$ in parity 2 (6.67\%) compared to parity 1 (13.63\%) and parity $\geq 3$ Karadi ewes $(10.42 \%)$.
However, dystocia rate and lamb mortality rate from birth to weaning were higher in parity $1 \quad$ (9.09\%; $\quad P=0.052 ; \quad 4.55 \% ; \quad \mathrm{P}=0.045$, respectively) ewes in compare to parity $2(3.33 \%$ and $0.00 \%$, respectively) and parity $\geq 3$ Karadi ewes $(2.08 \%$ and $0.00 \%$, respectively). There were no differences in fertility rate $(P=149)$, conception rate $(P=0.185)$, litter size or prolificacy $(P=199)$ and abortion rate $(P=114)$ between parity 1, 2 and $\geq 3$ Karadi ewes Table 5. 
Table (5): Effect of parity on reproductive performance in synchronized Karadi ( $n=100)$ ewes. Synchronized estrus Karadi Sheep $(n=100)$

\begin{tabular}{|c|c|c|c|c|}
\hline \multirow[t]{2}{*}{ Reproductive traits } & \multicolumn{3}{|c|}{ Parity of sheep } & \multirow[t]{2}{*}{$P$ value } \\
\hline & Parity 1; n=22 (\%) & Parity 2; n=30 (\%) & Parity $\geq 3, n=48$ (\%) & \\
\hline Fertility rate & 86.36 & 83.33 & 85.42 & 0.149 \\
\hline Conception rate & 95.20 & 90.00 & 89.58 & 0.185 \\
\hline Litter size or prolificacy & 1.21 & 1.40 & 1.19 & 0.199 \\
\hline Lambing rate & $104.50^{b}$ & $116.60^{\mathrm{a}}$ & $102.10^{b}$ & 0.018 \\
\hline Abortion rate & 4.55 & 6.66 & 4.17 & 0.114 \\
\hline Dystocia rate & $9.09^{\mathrm{a}}$ & $3.33^{b}$ & $2.08^{b}$ & 0.052 \\
\hline Mortality rate after birth & $4.34^{a}$ & $0.00^{\mathrm{b}}$ & $0.00^{b}$ & 0.045 \\
\hline Barrenness rate & $13.63^{\mathrm{a}}$ & $6.67^{b}$ & $10.42^{a}$ & 0.014 \\
\hline
\end{tabular}

Rates within rows with different superscript letters are significantly different $(\mathrm{P} \leq 0.05)$.

Regarding the effect of ewe parity 1,2 and $\geq 3$ on reproductive parameters in synchronized Awassi ewes which had synchronized oestrus (Table 6), lambing rate was lower $(P=0.054)$ in parity 1 $(104.35 \%)$ compared to parity $2(124.20 \%)$ and $\geq 3$ ewes $(115.90 \%)$, while lamb mortality rate $(\mathrm{P}=0.012 ; 8.33 \%)$ and ewes barrenness rate $(P=0.049 ; 8.65 \%)$ were higher in parity 1 Awassi ewes compared to parity 2 ewes $(0.00 \%$ and $3.03 \%$, respectively) and parity $\geq 3$ ewes
(1.96\% and $6.81 \%$, respectively). Abortion rate was lower $(P=0.016)$ in parity 2 ewes $(0.0 \%)$ compared to parity 1 ewes $(4.35 \%)$ and parity $\geq 3$ ewes $(4.45 \%)$. However, dystocia rate was lower $(P=0.027)$ in parity $\geq 3$ compared to parity 1 $(4.34 \%)$ and parity 2 ewes $(3.03 \%)$. There were no differences in fertility rate $(P=168)$, conception rate $(P=0.194)$ and litter size or prolificacy $(P=274)$ between parity 1,2 and $\geq 3$ synchronized Awassi ewes.

Table (6): Effect of parity on reproductive performance in synchronized Awassi $(n=100)$ ewes.

\begin{tabular}{|c|c|c|c|c|}
\hline \multirow[b]{3}{*}{ Reproductive traits } & \multicolumn{4}{|c|}{ Synchronized estrus Awassi sheep $(n=100)$} \\
\hline & \multicolumn{3}{|c|}{ Parity of sheep } & \multirow[t]{2}{*}{$P$ value } \\
\hline & Parity 1; n=23 (\%) & Parity 2; n=33 (\%) & Parity $\geq 3 ; n=44$ (\%) & \\
\hline Fertility rate & 86.96 & 93.94 & 90.91 & 0.168 \\
\hline Conception rate & 91.30 & 93.94 & 95.45 & 0.194 \\
\hline Litter size or prolificacy & 1.20 & 1.32 & 1.28 & 0.274 \\
\hline Lambing rate & $104.35^{\mathrm{a}}$ & $124.20^{\mathrm{b}}$ & $115.90^{b}$ & 0.054 \\
\hline Abortion rate & $4.34^{b}$ & $0.00^{\mathrm{a}}$ & $4.45^{\mathrm{b}}$ & 0.016 \\
\hline Dystocia rate & $4.34^{b}$ & $3.03^{b}$ & $0.00^{\mathrm{a}}$ & 0.027 \\
\hline Mortality rate after birth & $8.33^{\mathrm{c}}$ & $0.00^{\mathrm{a}}$ & $1.96^{\mathrm{b}}$ & 0.012 \\
\hline Barrenness rate & $8.65^{b}$ & $3.03^{\mathrm{a}}$ & $6.81^{\mathrm{b}}$ & 0.049 \\
\hline
\end{tabular}

Rates within rows with different superscript letters are significantly different $(\mathrm{P} \leq 0.05)$. 


\subsection{Effect of ram to ewe ratio on synchronized Karadi and Awassi ewes}

The effect of ram to ewe ratio 1:8, 1:12 and $1: \geq 16$ during oestrus period on reproductive performance in synchronized Karadi ewes are presented in Table 7. The conception rate was higher $(P=0.014)$ in ram to ewe ratio $1: 8$ group $(96.67 \%)$ compared to $1: \geq 16$ ram to ewe group $(82.50 \%)$, while there was no significant difference between ram to ewe ratio 1:8 and 1:12
(93.34\%). However, barrenness rate was higher $(P=0.012)$ in ram to ewe ratio $1: \geq 16$ group (17.5\%) compared to $1: 8(3.33 \%)$ and $1: 15$ ram to ewe group $(6.66 \%)$. There were no differences in fertility rate $(P=0.487)$, litter size or prolificacy $(P=0.274)$, lambing rate $(P=0.251)$, twinning rate $(P=0.368)$ and abortion rate $(P=0.262)$ between ram to ewe ratio 1:8, 1:12 and $1: \geq 16$ synchronized Karadi ewe groups.

Table (7): Effect of ram to ewe ratio on reproductive performance in synchronized Karadi $(n=100)$ ewes.

\begin{tabular}{|c|c|c|c|c|}
\hline \multirow[t]{2}{*}{ Reproductive traits } & \multicolumn{3}{|c|}{ Ram to ewe ratio in Synchronized estrus Karadi sheep $(n=100)$} & \multirow[t]{2}{*}{$P$ value } \\
\hline & $\begin{array}{c}1: 8 ; n=30 \\
(\%)\end{array}$ & $\begin{array}{c}1: 12 ; n=30 \\
(\%)\end{array}$ & $1: \geq 16 ; n=40$ (\%) & \\
\hline Fertility rate & 90.00 & 86.67 & 80.00 & 0.487 \\
\hline Conception rate & $96.67^{\mathrm{a}}$ & $93.34^{\mathrm{a}}$ & $82.50^{b}$ & 0.014 \\
\hline Litter size or prolificacy & 1.29 & 1.27 & 1.22 & 0.643 \\
\hline Lambing rate & 116.67 & 110.00 & 97.50 & 0.651 \\
\hline Twinning rate & 26.66 & 23.33 & 17.50 & 0.368 \\
\hline Abortion rate & 3.33 & 6.66 & 2.50 & 0.262 \\
\hline Barrenness rate & $3.33^{b}$ & $6.66^{b}$ & $17.50^{\mathrm{a}}$ & 0.014 \\
\hline
\end{tabular}

Rates within rows with different superscript letters are significantly different $(\mathrm{P} \leq 0.05)$.

The effect of ram to ewe ratio $1: 8,1: 12$ and $1: \geq 16$ during oestrus period on reproductive efficiency in synchronized Awassi ewes are presented in Table 8. The conception rate was trended to be higher $(P=0.051)$ in ram to ewe ratio $1: 8$ group $(96.67 \%)$ compared to $1: \geq 16$ $(87.50 \%)$, while there was no significant difference between $1: 8$ and $1: 12$ ram to ewe group (93.33\%). However, barrenness rate were higher $(P=0.053)$ in ram to ewe ratio $1: \geq 16$ group $(7.50 \%)$ compared to $1: 8$ ram to ewe ratio group $(3.33 \%)$, while there was no significant difference between group of ram to ewe ratio $1: \geq 16$ group and $1: 12$ ram to ewe group $(6.66 \%)$. There were no differences in fertility rate $(P=607)$, litter size or prolificacy $(P=0.158)$, lambing rate $(P=0.168)$, twinning rate $(P=0.328)$ and abortion rate $(P=0.275)$ between ram to ewe ratio $1: 8,1: 12$ and $1: \geq 16$ synchronized Awassi ewe 
Table (8): Effect of ram to ewe ratio on reproductive performance in synchronized Awassi $(\mathrm{n}=100)$ ewes.

\begin{tabular}{|c|c|c|c|c|}
\hline \multirow[t]{2}{*}{ Reproductive traits } & \multicolumn{3}{|c|}{ Ram to ewe ratio in Synchronized estrus Awassi sheep $(n=100)$} & \multirow[t]{2}{*}{$P$ value } \\
\hline & $\begin{array}{c}1: 8 ; n=30 \\
(\%)\end{array}$ & $1: 12 ; n=30(\%)$ & $1: \geq 16 ; n=40(\%)$ & \\
\hline Fertility rate & 93.33 & 93.33 & 87.50 & 0.607 \\
\hline Conception rate & $96.67^{\mathrm{a}}$ & $93.33^{\mathrm{a}}$ & $87.50^{b}$ & 0.051 \\
\hline Litter size or prolificacy & 1.32 & 1.32 & 1.20 & 0.158 \\
\hline Lambing rate & 123.30 & 123.30 & 105.00 & 0.168 \\
\hline Twinning rate & 32.14 & 32.14 & 17.50 & 0.368 \\
\hline Abortion rate & 3.33 & 0.00 & 5.00 & 0.475 \\
\hline Barrenness rate & $3.33^{b}$ & $6.66^{a}$ & $7.50^{a}$ & 0.055 \\
\hline
\end{tabular}

Rates within rows with different superscript letters are significantly different $(\mathrm{P} \leq 0.05)$.

\section{DISCUSSION}

\subsection{Effect of breed (Karadi vs Awassi ewes)}

4.1.1. Spontaneous Karadi vs spontaneous Awassi ewes

The result of the present study revealed that the twinning rate was significantly higher in spontaneous Awassi ewes compared to spontaneous Karadi ewes. These finding agree with Berhan and Van Arendonk (2006) who found that different breed of sheep had significantly different twining rate. These result of twinning rate in Awassi sheep (12.5\%) are within the range of twinning rate (12.3 to $13.7 \%$ ) found by Taha and Alkass (2011) in Awassi ewes. This finding of twining rate agrees with those of Edea et al. (2012) who found that the twinning rate in Horro sheep are (12.8\%). However, the twinning rate in the Karadi sheep breed are lower than those reported by Taha and Alkass (2011) and Edea et al. (2012). The lower rate of twinning in the Karadi sheep breed may be due to the genetic potential of Karadi could responsible for such lower twinning rate (Ghaffari et al., 2009). One of the main factor that facing sheep producer is early embryonic death which reduces the profitability of lamb production worldwide (Binns et al., 2002).

The lamb mortality rate after birth to weaning were more in spontaneous Awassi ewes compared to spontaneous Karadi ewes. The mortality rate recorded in Awassi sheep is agreeing with those reported by Taha and Alkass
(2011). However, the result of the present study is lower than the value (12.1\%) that found by Luttikholt et al. (2014). Awassi sheep are originally from the middle and south of Iraq, so higher lamb mortality rate in Awassi sheep could be due to the variations in climatic conditions, and, the availability of feed between Kurdistan region and the middle and south of Iraq.

\subsubsection{Synchronized Karadi vs synchronized Awassi ewes}

Abortion is considered one of the factors that significantly affects productivity in sheep flocks (Mahboub et al., 2013). In the present study, a significant higher abortion rate was recorded in synchronized Karadi ewes compared to synchronized Awassi ewes. These findings are consistent with those of Mahboub et al. (2013). They found that the proportion of abortion were affected by different sheep breeds in Egypt. In addition, the rate of abortion in the present study is within the range (1-25\%) reported by Mahboub et al. (2013) in Egypt sheep raised under farm condition. The different proportion of abortion in different breeds of sheep may due to the sensitivity of different breed of sheep to disease which causes abortion in sheep, especially viral, bacterial and protozoa (Toxoplasma gondii) infection from early embryonic term to the end of the gestation period (Mahboub et al., 2013).

In addition, the result showed that the rate of dystocia was higher in synchronized Karadi ewes compared to synchronized Awassi ewes. Several previous studies have shown that 
different breeds of ewes have a significant effect on dystocia rate (Binns et al., 2002). Higher dystocia rate in synchronized Karadi ewes compared to Awassi ewes may due to the higher average birth weight of Karadi lamb which leading to increased rates of dystocia (Binns et al., 2002; Amen and Ali, 2010). Because there is a positive relationship between lamb birth weight and dystocia (Amen and Ali, 2010). However, the result of the present recorded higher lambing rate in synchronized Awassi compared to synchronized Karadi ewes. The result of present study are within the range 75.6 - $114.6 \%$ found by Koyuncu and Alticekic (2010) in synchronized Kivircik ewes. Similarly, Abecia et al. (2007) found that lambing rate were significantly different in three breeds of sheep. As far as I am aware, this is the first study to compare between reproductive efficiency in synchronized Karadi and Awassi sheep.

Although the dystocia rate was more in Karadi ewes compared to Awassi ewes, the result found that lamb mortality rate was higher in synchronized Awassi compared to synchronized Karadi ewes. Several previous studies found that the breeds of sheep have had a significant effect on the rate of lamb mortality (Gama et al., 1991; Binns et al., 2002). In addition, similar to the current study, Taha and Alkass (2011) recorded a 4.0\% of lamb mortality in Awassi sheep. However, Mandal et al. (2007) recorded higher lamb mortality rate $12.6 \%$ in Muzaffarnagari sheep. The lamb mortality rate can be seen to vary substantially among the different breeds of sheep. Lower mortality in Karadi lamb is considered as a good indicator of Karadi lamb adaptations' to the environmental conditions in the region compared to the Awaasi lamb which are originally from the middle and south of Iraq Taha and Alkass (2011).

\subsection{Effect of parity of ewes \\ 4.2.1. Effect of parity on spontaneous Karadi and Awassi ewes}

In the current study, parity 1 ewes had a lower lambing rate compared to parity 2 and $\geq 3$ Karadi ewes. Similarly, a study conducted by Hanrahan and Quirke (1985) found also that lambing rate increase with increase ewe parity. The results of the present study are within the range (82.6-100\%) reported by Juma and Alkass (2005) in Iraqi native sheep. Lower lambing rate in younger ewes may be due to lower ovulation rate and lower fetal survival in younger ewes compared to older ewes (Shorten et al., 2013).
Dystocia is considered one of the main factors that cause lamb mortality in the sheep flock and also results in a great economic loss to the lamb producer (Amen and Ali, 2010). The result of the present study found that dystocia rate was more in parity 1 ewes compared to parity 2 and $\geq 3$ ewes. This finding also agree with the dystocia rate in a study conducted on Dorset Horn ewes by George et al (1976) of $30.12 \%$ in nulliparous ewes compared to multiparous ewes $(8.31 \%)$, respectively. The dystocia rate in in parity 1 ewes are within the range (3.53-10.58) reported by Mandal et al. (2007) in a study conducted on Muzaffarnagari sheep. High rates of dystocia among parity 1 ewes are mostly due to their smaller size and narrow birth canal at first parturition than at subsequent lambing (Gaafar et al., 2010). Globally, higher lamb mortality rate reduces the profitability of lamb production in sheep flock (Binns et al., 2002). The results of the present study agree with those of Woolliams et al. (1982). They recorded a highest lamb mortality rate in parity 1 ewes (13.4\%) and lowest in parity $2(11.1 \%)$ than parity $\geq 3(12.8 \%)$ ewes. The finding of the current study also conforms to expectation from the other previously published article (Dalton et al., 2001). Higher mortality rates in parity 1 dams may due to higher incidence of dystocia in parity 1 ewes and also mis-mothering in parity 1 ewes (Gama et al., 1991). Because there is a positive relationship between the rate of dystocia and lamb mortality rate (Mandal et al., 2007).

Regarding the effect of dam parity on spontaneous Awassi ewes' reproductive efficiency. The result of the present study shows that the lambing rate Awassi ewes was higher in parity 2 compared to parity 1 and $\geq 3$. The higher lambing rate in parity 2 ewes may be due to higher ovulation rate and higher fetal survival compared to younger and older ewes (Mandal et al., 2007). Current study found that lamb mortality rate was lower in parity 2 ewes compared to parity 1 and $\geq 3$ Awassi ewes. Similarly, Macleod et al. (1983) found the highest lamb mortality rate in parity 1 ewes $(13.4 \%)$ and lowest in parity $2(11.1 \%)$ than parity $\geq 3(12.8 \%)$ ewes. The finding of the current study conforms to expectation from the other previously published studies (Saacke et al., 2000). The lower mortality rate in parity 2 ewes may due to the lowest incidence of dystocia in parity 2 dams (Gama et al., 1991). 
Dystocia rate was higher in parity 1 ewes compared to parity 2 ewes and $\geq 3$ ewes. Similarly, the highest dystocia in nulliparous Dorset Horn (30.12\%) compared to multiparous $(8.31 \%)$ ewes was recorded by George et al. (1976). The dystocia rate in parity1 of Awassi ewes are within the range (3.53-10.58) of Muzaffarnagari sheep showed by Mandal et al. (2007). Higher rates of dystocia among parity 1 ewes are mostly due to their narrow birth canal at first parturition than at subsequent parity (Gaafar et al., 2010). Barrenness rate were lower in parity 2 ewes compared to parity 1 and $\geq 3$ Awassi ewes. The result of the current study is within the range (7.55-21.4\%) in Awassi ewes recorded by Abdulkareem and Eidan (2014). However, these results are lower than those reported by Alkass and Abdulkareem (2004) of 25\% in Awassi sheep. The evidence of lower barrenness rate in parity 2 ewes compared to parity 1 and $\geq 3$ Awassi ewes are unclear but generally agreed that parity 2 ewes are responsible for stronger oestrus and higher ovulation rate and consequently increased conception rate (Zebari et al., 2018).

\subsubsection{Effect of parity on synchronized Karadi and Awassi ewes}

An increase in lambing rate is one of the most important factors associated with profitability of a sheep farmers. The results showed that lambing rate was higher in parity 2 ewes compared to parity 1 and parity $\geq 3$ Karadi ewes. These results agree with those of Macedo (2016) who found that the lambing was higher in parity 2 (2.31 lambs/ewe) compared to parity 1 ewes (2.21 lamb/ewe) and parity $\geq 3$ (2.09 lamb/ewe) in Pelibuey purebred ewes. Abegaz et al. (2002) also reported higher lambing rate in parity 2 ewes $(81.5 \%)$ compared to parity $1(72.6 \%)$ and parity $\geq 3(81.2 \%)$ Horro sheep. In a study conducted by Rajab et al. (1992) found that lambing rate increased from parity $(126 \%)$ to parity 2 and $3(177 \%)$ than decreased to $143 \%$ of parity more than 4 ewes. The present study found a lower barrenness rate in parity 2 compared to parity 1 and parity $\geq 3$ Karadi ewes $(10.42 \%)$. This result is within the range (7.55$21.4 \%$ ) found in a survey study conducted on Awassi sheep by Abdulkareem and Eidan (2014). These results could be explained by the difference between the weights of the ewes at mating season of varying parity (Macedo, 2016). Several, previous studies reported a positive relationship (0.992) between the mating weight of the ewes and lambing rate (Avril et al., 2011).
The result showed a higher dystocia rate in parity 1 ewes in comparison to parity 2 ewes and parity $\geq 3$ Karadi ewes. Similarly, George et al. (1976) found that dystocia rate was higher in nulliparous ewes (30.12\%) compared to multiparous $(8.31 \%)$ Dorset Horn ewes. This result is within the range recorded by Mandal et al. (2007) of 3.53 to 10.58 in Muzaffarnagari sheep. The results of the current study also showed higher lamb mortality rate in parity 1 ewes compared to parity 2 ewes and parity $\geq 3$ Karadi ewes. This result agrees with those reported by Macleod et al. (1983) who found that lamb mortality rate was more in parity 1 ewes $(13.4 \%)$ compared to parity $2(11.1 \%)$ and parity $\geq 3(12.8 \%)$ ewes. The higher incidence of lamb mortality in parity 1 dam may due to the higher dystocia rate in parity one ewes compared to other parity. Previous studied found a positive relationship between lamb mortality rate and the rate of dystocia at parturition (Gama et al., 1991; Abegaz et al., 2002).

The result found that the lower lambing rate was recorded in parity 1 Awassi ewes compared to parity 2 and $\geq 3$ ewes. This results are constant with those found by Abegaz et al. (2002) who reported higher lambing rate in parity 2 ewes (81.5\%) compared parity 1 ewes (72.6\%) and parity $\geq 3(81.2 \%)$ Horro sheep. In another study conducted by Rajab et al. (1992) also found the lower lambing rate in parity 1 ewes (126\%) compared to parity 2 (177\%) and 3 ewes $(143 \%)$. Regarding the effect of dam parity on lamb mortality rate, higher lamb mortality rate was recorded in parity 1 ewes compared to parity 2 and parity $\geq 3$ ewes. Similarly, Woolliams et al. (1982) recorded significantly highest lamb mortality rate from in parity 1 ewes (13.4\%) compared to parity $2(11.1 \%)$ and parity $\geq 3 \quad(12.8 \%)$ ewes. Higher mortality rates in parity 1 dams may due to mismothering of parity 1 ewes (Green and Morgan, 1993). In contrast to the result of the present study, Macedo (2016) recorded lower lamb mortality rate in parity 1 ewes $(5.37 \%)$ and highest in parity 2 ewes $(16.22 \%)$ then parity 3 and 4 ewes (13.04 and 13.04, respectively) in Pelibuey ewes raised under an intensive tropical management. This difference may due to the effect of breed on lambing rate (Ghaffari et al., 2009).

The abortion rate was lower in parity 2 ewes compared to parity 1 and parity $\geq 3$ ewes. The highest abortion rate in parity 1 and $\geq 3$ ewes are unclear. However, the results of the present study showed that dystocia rate was lower in 
parity $\geq 3$ compared to parity 1 and parity 2 ewes. Similarly, Smith (1977) found that parity 2 ewes (9\%) had a significantly lower dystocia rate compared to parity $1(14 \%)$ and parity 3 ewes (12\%). The highest dystocia in parity 1 ewes may due to failure of the cervix (ring womb) to dilate sufficiently during parturition in order to promote delivery of the lambs (Noaman et al., 2013). The failure of a ewe to lamb during the normal lambing season is called barrenness (Purser, 1965). The current study found highest ewe barrenness rate in parity 1 ewes compared to parity 2 and parity $\geq 3$ Awassi ewes. This results are constant with that of Kelly and Johnstone (1983) who found a higher barrenness rate in parity 1 ewes. However, Juma and Alkass (2005) recorded higher barrenness rate of $25 \%$ in Awassi sheep. The higher percentage of barrenness in parity 1 ewes may due to the partial failure of ovulations in parity 1 ewes (Shorten et al., 2013).

\subsection{Effect of ram to ewe ratio on synchronized ewes}

The effect of ram to ewe ratio 1:8, 1:12 and $1: \geq 16$ during oestrus period on reproductive performance in synchronized Karadi and Awassi sheep. The result showed that the conception rate was higher in the ram to ewe ratio 1:8 group compared to $1: \geq 16$ ram to ewe group. This findings are constant with that reported by Evans et al. (2004) who found that conception rate increase with increasing the number of rams introduced to ewe during breeding season after removal of sponges. Increasing ovulation with an increase ram to ewe ratio may due to that exposure ewes to rams advanced the timing of the LH surge and ovulation rate (Evans et al., 2004). The current study found that barrenness rate was higher in ram to ewe ratio $1: \geq 16$ group compared to 1:8 ram to ewe ratio group and 1:12 ram to ewe group. In a study conducted on Suffolk-cross breed sheep by (Evans et al., 2004; Gaskins et al., 2005) showed that the rate of ewe barrenness decrease with increase the number of rams exposed to ewe after withdrawal of sponges. The number of ram could stimulate in FSH secretion, which lead to an increase of oestradiol production from the dominant follicles (Atkinson and Williamson, 1985). Then after withdrawal of sponge lead to a more rapid onset of oestrus and increase the length of oestrus, this give more opportunity to concept the ewe (Atkinson and Williamson, 1985).

\section{CONCLUSION}

The breed had an effect on some reproductive parameters in synchronized and spontaneous ewes. In synchronized and spontaneous Karadi and Awassi ewes parity 2 had higher reproductive performance than parity 1 and parity $\geq 3$ ewes. Conception rate was higher in $1: 8$ ram ewe ratio group, while $1: \geq 16$ ram to ewe ratio group had a higher barrenness rate.

\section{ACKNOWLEDGEMENT:}

The authors would like to thank the owner of the sheep flock farms for their support.

\section{REFERENCES}

Abdulkareem, T. A. and Eidan, S. M. (2014). Reproductive performance of iraqi Awassi ewes owned by sheep owner and extension farms in response to flushing and estrus. The Iraqi Journal of Agricultural Sciences, 45 (3), pp. 328-334.

Abecia, J.A., Valares, J.A., Forcada, F., Palacin, I., Martin, S. and Martino, A., 2007. The effect of melatonin on the reproductive performance of three sheep breeds in Spain. Small Ruminant Research, 69(1-3), pp.10-16.

Abegaz, S., Duguma, G., Negussie, E., Gelmesa, U., Terefe, F. and REGE, J.E.O., 2002. Factors affecting reproductive performance and estimates of genetic parameters of litter size in Horro sheep. The Journal of Agricultural Science, 139(1), p.79.

Amen, F.A. and Ali, T.G., 2010. Treatments of dystocia in Karadi ewes in Sulaimani Province. Basrah Journal of Veterinary Research., 9(1), pp.35-39.

Alkass, J.E., Abdulkareem, T.A. and Al-Mjamei, S.M., 2004. Reproductive performance of Iraqi Awassi ewes in response to treatment with equine chorionicgondortropin. Significance, 100 (T1), p.T2.

Atkinson, S. and Williamson, P., 1985. Raminduced growth of ovarian follicles and gonadotrophin inhibition in anoestrous ewes. Reproduction, 73(1), pp.185-189.

Avril, D., Lallo, C.H., Percy, K., Bourne, G., Thomas, P. and Warner, R., 2011. Pre-wean performance of lambs from Barbados Black belly and West African type ewes reared under a pasture based system in the humid tropical environment of Tobago, West Indies. Tropical Agriculture (Trinidad), 88, pp.232-243.

Berhan, A. and Van Arendonk, J., 2006. Reproductive performance and mortality rate in Menz and Horro sheep following controlled breeding in Ethiopia. Small Ruminant 
Research, 63(3), pp.297-303.

Binns, S.H., Cox, I.J., Rizvi, S. and Green, L.E., 2002. Risk factors for lamb mortality on UK sheep farms. Preventive veterinary medicine, 52(3-4), pp.287-303.

Buckley, F., O'sullivan, K., Mee, J.F., Evans, R.D. and Dillon, P., 2003. Relationships among milk yield, body condition, cow weight, and reproduction in spring-calved HolsteinFriesians. Journal of dairy science, 86(7), pp.2308-2319.

Crosby, T.F., Boland, M.P. and Gordon, I., 1991. Effect of progestagen treatments on the incidence of oestrus and pregnancy rates in ewes. Animal reproduction science, 24(1-2), pp.109-118.

Dalton, J.C., Nadir, S., Bame, J.H., Noftsinger, M., Nebel, R.L. and Saacke, R.G., 2001. Effect of time of insemination on number of accessory sperm, fertilization rate, and embryo quality in dairy cattle. Journal of dairy science, 84(11), pp.2413-2418.

Edea, Z., Haile, A., Tibbo, M., Sharma, A.K., Sölkner, J. and Wurzinger, M., 2012. Sheep production systems and breeding practices of smallholders in western and south-western Ethiopia: Implications for designing community-based breeding strategies. Livestock Research for Rural Development, 24(7), p.2012.

Evans, A.C.O., 2003. Ovarian follicle growth and consequences for fertility in sheep. Animal Reproduction Science, 78(3-4), pp.289-306.

Evans, A.C.O., Duffy, P., Crosby, T.F., Hawken, P.A.R., Boland, M.P. and Beard, A.P., 2004. Effect of ram exposure at the end of progestagen treatment on estrus synchronisation and fertility during the breeding season in ewes. Animal reproduction science, 84(3-4), pp.349-358.

Gaafar, H.M.A., Shamiah, S.M., Shitta, A.A. and Ganah, H.A.B., 2010. Some factors affecting on retained placenta and its effects on postpartum reproductive performance and milk production of Friesian cows. Slovak Journal of animal science, 43(1), pp.6-12.

Galal, S., Gürsoy, O. and Shaat, I., 2008. Awassi sheep as a genetic resource and efforts for their genetic improvementA. Small Ruminant Research, 79(2-3), pp.99-108.

Gama, L.T., Dickerson, G.E., Young, L.D. and Leymaster, K.A., 1991. Genetic and phenotypic variation in sources of preweaning lamb mortality. Journal of animal science, 69(7), pp.2744-2753.

Gaskins, C.T., Snowder, G.D., Westman, M.K. and Evans, M., 2005. Influence of body weight, age, and weight gain on fertility and prolificacy in four breeds of ewe lambs. Journal of Animal Science, 83(7), pp.1680-1689.

Ghaffari, M., Nejati-Javaremi, N. and RahimiMianji, G., 2009. Lack of polymorphism in the oocyte derived growth factor (GDF9) gene in the Shal breed of sheep. South African Journal of Animal Science, 39(4).

Green, L.E. and Morgan, K.L., 1993. Mortality in early born, housed lambs in south-west England. Preventive Veterinary Medicine, 17(3-4), pp.251-261.

Hanrahan, J. P. and Quirke, J. F. (1985). Contribution of variation in ovulation rate and embryo survival to within breed variation in litter size.Animal Science,5(3),pp.21-25.

George, J.M., 1976. The incidence of dystocia in Dorset Horn ewes. Australian Veterinary Journal, 52(11), pp.519-523.

Juma, K.H. and Alkass, J.E., 2005. Native goats of Iraq: A review. Dirasat Agricultural Sciences, 32(2), pp.180-188.

Kelly, R.W. and Johnstone, P.D., 1983. Influence of site of ovulation on the reproductive performance of ewes with 1 or 2 ovulations. New Zealand Journal of Agricultural Research, 26(4), pp.433-435.

Koyuncu, M. and Altıcekic, S.O., 2010. Effects of progestagen and PMSG on estrous synchronization and fertility in Kivircik ewes during natural breeding season. AsianAustralasian Journal of Animal Sciences, 23(3), pp.308-311.

Lucidi, P., Barboni, B. and Mattioli, M., 2001. Ram-induced ovulation to improve artificial insemination efficiency with frozen semen in sheep. Theriogenology, 55(9), pp.1797-1805.

Luttikholt, S., Veldhuis, A., van den Brom, R., Moll, L., Lievaart-Peterson, K., Peperkamp, K., van Schaik, G. and Vellema, P., 2014. Risk factors for malformations and impact on reproductive performance and mortality rates of Schmallenberg virus in sheep flocks in the Netherlands. PloS one, 9(6), p.e100135.

Macedo, R. and Hummel, J.D., 2016. Influence of parity on productive performance of Pelibuey ewes under intensive management in the Mexican dry tropics. Livestock Research for Rural Development, 18(6), pp.1-9.

Macleod, N. S. M., Wiener, G. and Woolliams, C. (1983). The effects of breed, breeding system and other factors the effects of breed, breeding system and other factors on lamb mortality', The Journal of Agricultural Science, 100(3), pp. 571-580.

Mahboub, H.D., Helal, M.A., Abd Eldaim, M.A., Abd El-Razek, E.M. and Elsify, A.M., 2013. Seroprevalence of abortion causing agents in 
egyptian sheep and goat breeds and their effects on the animal's performance. Journal of Agricultural Science, 5(9), p.92.

Mandal, A., Prasad, H., Kumar, A., Roy, R. and Sharma, N., 2007. Factors associated with lamb mortalities in Muzaffarnagari sheep. Small Ruminant Research, 71(1-3), pp. 273-279.

Naoman, U.D., Jabbo, S.S., Ahmed, M.A. and Ahmed, A.E., 2013. Causes and treatment of dystocia in awassi ewes. Basrah Journal of Veterinary, 12(2),pp.250-255.

Rajab, M.H., Cartwright, T.C., Dahm, P.F. and Figueiredo, E.A.P., 1992. Performance of three tropical hair sheep breeds. Journal of Animal Science, 70(11), pp.3351-3359.

Saacke, R.G., Dalton, J.C., Nadir, S., Nebel, R.L. and Bame, J.H., 2000. Relationship of seminal traits and insemination time to fertilization rate and embryo quality. Animal reproduction science, 60, pp.663-677.

Shorten, P.R., O'Connell, A.R., Demmers, K.J., Edwards, S.J., Cullen, N.G. and Juengel, J.L., 2013. Effect of age, weight, and sire on embryo and fetal survival in sheep. Journal of Animal Science, 91(10), pp.4641-4653.

Smith, G.M., 1977. Factors affecting birth weight, dystocia and preweaning survival in sheep. Journal of Animal Science, 44(5), pp.745-753.

Taha, V. and Alkass, J. E. (2011). A Survey Study Of Sheep And Goats Raised Under Farm Conditions. Journal of university of Duhok (Agr. and Vet. Sci.), 14(1), pp.120-125.

Woolliams, J.A., Suttle, N.F., Wiener, G. and Field, A.C., 1982. Genetic and dietary factors in $\mathrm{Cu}$ accumulation by sheep. In Proceedings. symposium on Trace element metabolism in man and animals.

Zebari, H.M., Rutter, S.M. and Bleach, E.C., 2018. Characterizing changes in activity and feeding behaviour of lactating dairy cows during behavioural and silent oestrus. Applied Animal Behaviour Science, 206, pp.12-17. 